\title{
Parents' experiences of caring for a young child with type 1 diabetes: a systematic review and synthesis of qualitative evidence
}

\author{
B. Kimbell ${ }^{1 *}$ (D) J. Lawton ${ }^{1}$, C. Boughton ${ }^{2}$, R. Hovorka ${ }^{2,3}$ and D. Rankin ${ }^{1}$
}

\begin{abstract}
Aims: To synthesise the qualitative evidence on parents' experiences of caring for a child aged $\leq 8$ years with type 1 diabetes to identify: the challenges they encounter; their views about support received; ways in which support could be improved; and, directions for future research.

Methods: We searched Medline, EMBASE, CINAHL, PsycINFO and Web of Science databases to identify qualitative studies reporting parents' views and experiences of caring for a child with type 1 diabetes aged $\leq 8$ years. Key analytical themes were identified using thematic synthesis.

Results: Fourteen studies were included. The synthesis resulted in the generation of two overarching themes. Monopolisation of life describes the all-encompassing impact diabetes could have on parents due to the constant worry they experienced and the perceived need for vigilance. It describes how parents' caring responsibilities could affect their wellbeing, relationships and finances, and how a lack of trusted sources of childcare and a desire to enable a 'normal' childhood constrained personal choices and activities. However, use of diabetes technologies could lessen some of these burdens. Experiences of professional and informal support describes how encounters with healthcare professionals, while generally perceived as helpful, could lead to frustration and anxiety, and how connecting with other parents caring for a child with type 1 diabetes provided valued emotional and practical support.

Conclusions: This synthesis outlines the challenges parents encounter, their views about support received and ways in which support might be improved. It also highlights significant limitations in the current literature and points to important areas for future research, including how sociodemographic factors and use of newer diabetes technologies influence parents' diabetes management practices and experiences.

PROSPERO: https://www.crd.york.ac.uk/prospero/display_record.php?ID=CRD42019128710
\end{abstract}

Keywords: Type 1 diabetes, Parents, Child, Qualitative synthesis

* Correspondence: barbara.kimbell@ed.ac.uk

${ }^{1}$ Centre for Population Health Sciences, Usher Institute, University of Edinburgh, Edinburgh, UK

Full list of author information is available at the end of the article

(c) The Author(s). 2021 Open Access This article is licensed under a Creative Commons Attribution 4.0 International License, which permits use, sharing, adaptation, distribution and reproduction in any medium or format, as long as you give appropriate credit to the original author(s) and the source, provide a link to the Creative Commons licence, and indicate if changes were made. The images or other third party material in this article are included in the article's Creative Commons licence, unless indicated otherwise in a credit line to the material. If material is not included in the article's Creative Commons licence and your intended use is not permitted by statutory regulation or exceeds the permitted use, you will need to obtain permission directly from the copyright holder. To view a copy of this licence, visit http://creativecommons.org/licenses/by/4.0/. The Creative Commons Public Domain Dedication waiver (http://creativecommons.org/publicdomain/zero/1.0/) applies to the data made available in this article, unless otherwise stated in a credit line to the data. 


\section{Background}

Type 1 diabetes is one of the most common chronic childhood conditions and its incidence is rising worldwide [1], including among pre-school aged children [2]. This condition is now mostly managed using flexible intensive insulin regimens, which involve multiple daily tasks (e.g. regular blood glucose monitoring, carbohydrate counting, calculating and administering insulin) and may present different issues and challenges to conventional regimens based on fixed schedules and insulin doses. For young children (those aged $\leq 8$ years), however, most of these tasks are too complex to undertake independently; hence, parents/caregivers typically take on and/or oversee these responsibilities [3]. The physiological, cognitive, behavioural and socio-emotional issues at this developmental stage make diabetes management challenging [4] and clinically recommended blood glucose targets difficult to achieve [5]. Hence, caring for a young child with diabetes can be overwhelming and stressful for parents, and can affect wider family life [6].

Qualitative studies have explored parents' experiences of caring for a child with type 1 diabetes in a range of contexts and situations, such as following diagnosis, using different diabetes management regimens and whilst managing transitions [7-11]. Synthesising bodies of qualitative literature can help clarify understanding of a phenomenon, identify gaps and ambiguities in the existing literature, and inform decision-making by policymakers and healthcare practitioners [12]. However, syntheses of qualitative or mixed-methods research involving parents of young children with type 1 diabetes remain scarce and have generally focused on specific aspects of their experience, such as their psychological reactions to their child's diagnosis [13] or their use of diabetes technologies [14]. To date, no reviews have focused on parents' everyday experiences of caring for a young child with type 1 diabetes. This review aims to address this gap. By identifying, examining and synthesising the qualitative evidence on parents' experiences of caring for a young child with type 1 diabetes, we sought to: (1) describe the published evidence base; (2) identify the challenges parents encounter when managing their child's diabetes; (3) explore their views about support received from health professionals and other sources; (4) identify ways in which support could be improved; and (5) identify gaps in the evidence base and directions for future research.

\section{Methods}

We followed Thomas and Harden's thematic synthesis approach, which is well suited to reviews focused on individuals' perspectives and experiences [15]. This approach involves a systematic search of relevant literature, quality appraisal of the included studies and three distinct stages of data manipulation: (1) line-byline coding, (2) organising codes into descriptive themes, and (3) developing analytic themes. Our reporting follows the guidelines for Enhancing Transparency of Reporting the Synthesis of Qualitative Research (ENTR EQ) and Preferred Reporting Items for Systematic Reviews and Meta-Analyses (PRISMA) [16, 17].

Details of the protocol for this systematic review and synthesis were registered on PROSPERO (https://www. crd.york.ac.uk/prospero/display_record.php? ID= CRD42019128710).

\section{Search strategy}

We identified papers for inclusion from a systematic search of electronic databases (Medline, EMBASE, CINA HL, PsycINFO and Web of Science). Working with a medical library science professional, we developed a search strategy that drew on existing literature and a combination of Medical Subject Heading (MeSH) terms and keywords relating to our target condition, population and methodology. Our searches were also informed by the SPIDER (Sample, Phenomenon of Interest, Design, Evaluation, Research type) approach to identifying qualitative literature [18] and search terms were tailored to suit each database. We screened the reference lists of included studies and relevant reviews identified by the search to identify further papers for inclusion. We limited our search to papers published from 2002 onwards, as this was the time when flexible intensive insulin regimens began to be widely used as part of routine clinical care [19]. A sample search strategy for Medline database is presented in supplementary figure Fig. S1.

\section{Study selection and screening}

Our choice of age cut-off at $\leq 8$ years was informed by the literature highlighting the high level of parental responsibility for diabetes management tasks in this younger age group [3]. Subsequently, increasing maturity and independence sees children assume progressively more responsibility for their own diabetes care; this transition changes parents' role in their child's diabetes management, and thus their experiences, and was outside the scope of this review.

We included peer-reviewed papers published in English if they reported: (1) primary research using qualitative methods or mixed-methods studies reporting qualitative data separately; and (2) views and/or experiences of parents and/or caregivers of children with type 1 diabetes $\leq 8$ years of age. This included studies which also reported the views of parents of older children, but where findings pertaining to those with children aged $\leq 8$ years and cutting across age ranges were clearly discernible. We had originally excluded some cross-cutting papers involving only a small number of parents of 


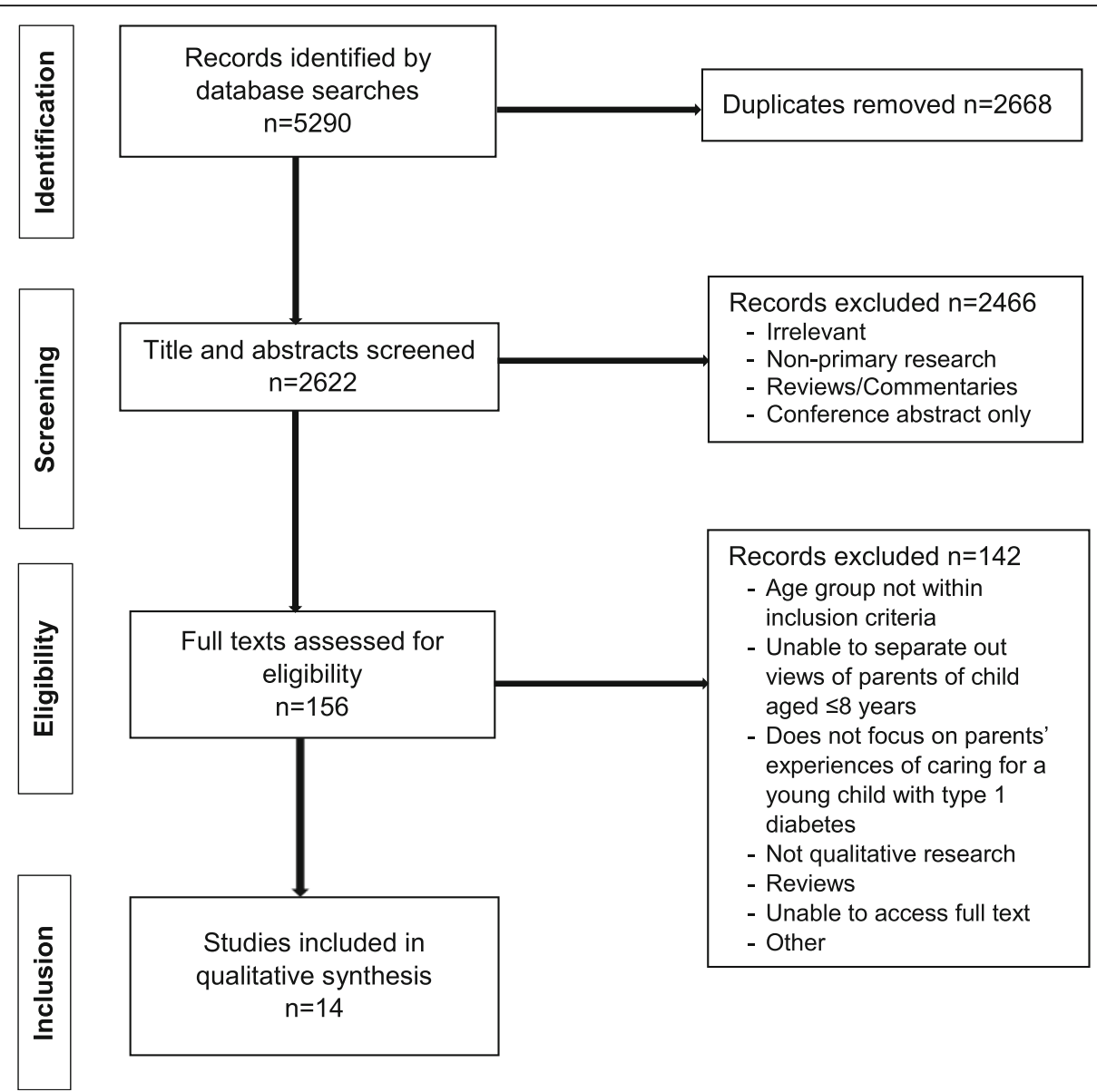

Fig. 1 PRISMA flow chart of study selection process

children in our target age range. However, a later reevaluation found these studies contributing important cultural and sociodemographic dimensions to the overall analysis, which warranted their inclusion. We excluded papers if they reported: (1) non-primary research; (2) only quantitative research; (3) data that focused exclusively on: parent/caregiver views and/or experiences regarding their child being diagnosed or immediately after diagnosis (which have been reviewed elsewhere [20]); parents of children older than 8 years with type 1 diabetes; and, adults with type 1 diabetes reporting their own experiences of living with type 1 diabetes.

Search outputs were imported into EndNote X8, then exported, de-duplicated and screened using Covidence systematic review management software (Veritas Health Innovation, Melbourne, Australia). To reduce selection bias, two authors (BK and DR) independently screened the titles and abstracts of identified records and compared and agreed their selections. Full texts were retrieved for any papers that appeared to meet the eligibility criteria. Disagreements on the final selection were minimal and resolved through discussion without need for third-party arbitration.

\section{Data extraction and quality assessment}

BK extracted the following data from the included studies: author(s); year of publication; country; study aims; sample size; parent and child characteristics; methodology. For each paper, we imported full 'Results' and 'Discussion' sections into NVivo 10 (QRS International, Doncaster, Australia). We extracted quotations and descriptive reporting of parents' accounts from Results sections only when this material could be clearly attributed to parents of children $\leq 8$ years of age. No findings (quotations or descriptive material) were extracted which reported the views of parents of children aged $>8$ years. In keeping with our aim to identify ways in which support for parents could be improved, we extracted recommendations in Discussion sections proffered by the primary authors. Recommendations made by primary authors were only extracted when these could be clearly attributed to children $\leq 8$ years of age, or where these were cross-cutting. 
Table 1 Characteristics of studies included in the qualitative synthesis

\begin{tabular}{|c|c|c|c|c|c|c|}
\hline Reference & Country & Study aim & $\begin{array}{l}\text { Parent } \\
\text { characteristics }\end{array}$ & $\begin{array}{l}\text { Child } \\
\text { characteristics }\end{array}$ & Method & Data analysis \\
\hline $\begin{array}{l}\text { Boman } \\
\text { et al., } 2013 \\
{[31]}\end{array}$ & Sweden & $\begin{array}{l}\text { To explore and discuss how } \\
\text { fathers involved in caring for a } \\
\text { child with T1D experience } \\
\text { support from paediatric diabetes } \\
\text { teams in everyday life. }\end{array}$ & $\begin{array}{l}n=11 \text { (all } \\
\text { fathers) } \\
\text { Age: } 37-51 \\
\text { years } \\
\text { Cohabiting } \\
\text { with mother: } \\
n=7 \\
\text { Higher } \\
\text { education: } n= \\
5\end{array}$ & $\begin{array}{l}n=11 \text { ( } \leq 8 \text { yo } \\
n=6) \\
\text { Age: } 4-16 \\
\text { years } \\
\text { Diabetes } \\
\text { duration: } 2-8 \\
\text { years }\end{array}$ & $\begin{array}{l}\text { Online focus group discussion } \\
\text { ( } n=6 \text { fathers); semi- } \\
\text { structured interviews ( } n=8 \\
\text { fathers) (mix of phone and } \\
\text { face-to-face); both ( } n=3 \\
\text { fathers) }\end{array}$ & $\begin{array}{l}\text { Constructivist grounded } \\
\text { theory analysis }\end{array}$ \\
\hline $\begin{array}{l}\text { Elissa } \\
\text { et al., } 2017 \\
\text { [35] }\end{array}$ & Palestine & $\begin{array}{l}\text { To explore the experiences of } \\
\text { daily life in children with T1D } \\
\text { and their parents living in the } \\
\text { West Bank in Palestine }\end{array}$ & $\begin{array}{l}n=10 \text { (6 } \\
\text { mothers) } \\
\text { Age mothers: } \\
\text { 28-49 years } \\
\text { Age fathers: } \\
\text { 32-42 years } \\
\text { Cohabiting: all } \\
\text { Higher } \\
\text { education: } n= \\
3 \\
\text { In } \\
\text { employment: } \\
n=4 \text { (fathers) } \\
\text { Rural or camp } \\
\text { living: } n=4\end{array}$ & $\begin{array}{l}n=10 \\
\text { Age: } 8-16 \\
\text { years } \\
\text { Diabetes } \\
\text { duration: }<5 \\
\text { years }(n=3) ; \\
1-5 \text { years }(n= \\
4) ;>5 \text { years } \\
(n=3)\end{array}$ & Face-to-face interviews & $\begin{array}{l}\text { Qualitative content } \\
\text { analysis as per } \\
\text { Graneheim \& Lundman } \\
\text { (2004) }\end{array}$ \\
\hline $\begin{array}{l}\text { Iversen } \\
\text { et al., } 2018 \\
\text { [33] }\end{array}$ & Norway & $\begin{array}{l}\text { To explore the lived experience } \\
\text { of being mothers and fathers of } \\
\text { a young child with T1D aged 1- } \\
7 \text { who had had the diagnosis } \\
\text { for at least } 1 \text { year. }\end{array}$ & $\begin{array}{l}n=15(8 \\
\text { mothers) } \\
\text { Age mothers: } \\
\text { 26-40 years } \\
\text { (m=30) } \\
\text { Age fathers: } \\
\text { 29-46 ( } m=38) \\
\text { Cohabiting: } 7 \\
\text { couples, } 1 \\
\text { single mother } \\
\text { In } \\
\text { employment: } \\
\text { all }\end{array}$ & $\begin{array}{l}n=8 \\
\text { Age: 1-7 years } \\
\text { Age at } \\
\text { diagnosis: } 1-5 \\
\text { years } \\
\text { Diabetes } \\
\text { duration: } 1-6 \\
\text { years } \\
\text { MDI (pen): } n= \\
1 \\
\text { CSII: } n=7\end{array}$ & $\begin{array}{l}\text { In-depth face-to-face inter- } \\
\text { views (one by telephone) }\end{array}$ & $\begin{array}{l}\text { Interpretative } \\
\text { phenomenological } \\
\text { methodology as } \\
\text { described by Van Manen }\end{array}$ \\
\hline $\begin{array}{l}\text { Khandan } \\
\text { et al., } 2018 \\
\text { [34] }\end{array}$ & Iran & $\begin{array}{l}\text { To explore the experiences of } \\
\text { mothers with diabetic children } \\
\text { after the transfer of caring role }\end{array}$ & $\begin{array}{l}n=11 \text { (all } \\
\text { mothers) } \\
\text { Age: } 30-48 \\
\text { years } \\
\text { Cohabiting: } \\
n=9 \\
\text { Higher } \\
\text { education: } n= \\
8 \\
\text { In } \\
\text { employment: } \\
n=5\end{array}$ & $\begin{array}{l}n=11 \\
\text { Age: } 7-14 \\
\text { years ( } \leq 8 \text { yo } \\
n=3 \text { ) } \\
\text { Diabetes } \\
\text { duration: } 12- \\
96 \text { months }\end{array}$ & $\begin{array}{l}\text { Semi-structured and open- } \\
\text { ended face-to-face interviews }\end{array}$ & Analysis as per Colaizzi \\
\hline $\begin{array}{l}\text { Lawton } \\
\text { et al., } 2015 \\
{[28]}\end{array}$ & UK & $\begin{array}{l}\text { To explore the difficulties } \\
\text { parents encounter in trying to } \\
\text { achieve clinically recommended } \\
\text { blood glucose levels. }\end{array}$ & $\begin{array}{l}n=54 \text { (38 } \\
\text { mothers) } \\
\text { Age all parents: } \\
25-51 \text { years } \\
\text { (m=40.6 } \pm 6.1) \\
\text { Cohabiting: } \\
70 \% \\
\text { Higher } \\
\text { education: } \\
27.8 \% \\
\text { In } \\
\text { employment: } \\
68.5 \%\end{array}$ & $\begin{array}{l}n=41 \\
\text { Age: } 2-12 \\
\text { years }(\mathrm{m}= \\
8.4 \pm 2.5) \\
\text { Age at } \\
\text { diagnosis: } 3- \\
10 \text { years ( } \mathrm{m}= \\
5.2 \pm 2.1) \\
\text { Diabetes } \\
\text { duration: } 1-11 \\
\text { years }(\mathrm{m}= \\
4.1 \pm 2.9) \\
\text { CSII: } 31.7 \%\end{array}$ & $\begin{array}{l}\text { In-depth face-to-face } \\
\text { interviews }\end{array}$ & $\begin{array}{l}\text { General theoretical and } \\
\text { procedural direction } \\
\text { taken from Grounded } \\
\text { Theory research }\end{array}$ \\
\hline Lindström & Sweden & To experience how mothers & $n=21$ (all & $n=22$ & Semi-structured, face-to-face & Inductive content \\
\hline
\end{tabular}


Table 1 Characteristics of studies included in the qualitative synthesis (Continued)

\begin{tabular}{|c|c|c|c|c|c|c|}
\hline Reference & Country & Study aim & $\begin{array}{l}\text { Parent } \\
\text { characteristics }\end{array}$ & $\begin{array}{l}\text { Child } \\
\text { characteristics }\end{array}$ & Method & Data analysis \\
\hline $\begin{array}{l}\text { et al., } 2017 \\
\text { [32] }\end{array}$ & & $\begin{array}{l}\text { experiencing burnout describe } \\
\text { mothering a child with diabetes, } \\
\text { with special focus on their need } \\
\text { for control and self-esteem. }\end{array}$ & $\begin{array}{l}\text { mothers) } \\
\text { Age: } 31-50 \\
\text { years (m=41) } \\
\text { Cohabiting: } \\
85.7 \% \\
\text { Higher } \\
\text { education: } \\
71.5 \% \\
\text { In } \\
\text { employment: } \\
90.4 \%\end{array}$ & $\begin{array}{l}\text { Age: } 3-17 \\
\text { years }(\mathrm{m}= \\
10.7) \\
\text { Diabetes } \\
\text { duration: } 1.5- \\
15 \text { years ( } \mathrm{m}= \\
5.3 \text { ) } \\
\text { CSII: } 77 \%\end{array}$ & interviews & analysis \\
\hline $\begin{array}{l}\text { Marshall } \\
\text { et al., } 2009 \\
\text { [30] }\end{array}$ & UK & $\begin{array}{l}\text { To explore and describe the } \\
\text { experiences of children and } \\
\text { their parents living with T1D } \\
\text { from diagnosis onwards }\end{array}$ & $\begin{array}{l}n=11 \text { (10 } \\
\text { mothers) } \\
\text { Ethnicity: Asian, } \\
\text { Eastern } \\
\text { European, } \\
\text { Jamaican, Irish, } \\
\text { English } \\
\text { backgrounds }\end{array}$ & $\begin{array}{l}n=10 \text { ( } \leq 8 \text { yo } \\
n=4) \\
\text { Age: } 4-17 \\
\text { years } \\
\text { Diabetes } \\
\text { duration: } 10 \\
\text { months - } 8 \\
\text { years }\end{array}$ & Conversational interviews & $\begin{array}{l}\text { Van Manen's } \\
\text { phenomenological } \\
\text { approach to thematic } \\
\text { coding }\end{array}$ \\
\hline $\begin{array}{l}\text { Patton } \\
\text { et al., } 2016 \\
{[26]}\end{array}$ & US & $\begin{array}{l}\text { To describe parents' perceptions } \\
\text { of healthful eating for T1D in } \\
\text { families of young children and } \\
\text { identify factors related to } \\
\text { parents' dietary management in } \\
\text { young children. }\end{array}$ & $\begin{array}{l}n=23(21 \\
\text { mothers) } \\
\text { Age all parents: } \\
27-49 \text { years } \\
(m=35.7 \pm 5.1) \\
\text { Married: } 83 \% \\
\text { Higher } \\
\text { education: } 87 \%\end{array}$ & $\begin{array}{l}n=\text { not } \\
\text { specified } \\
\text { Age: } 2-6.9 \\
\text { years (m }= \\
4.6 \pm 1.3 \text { ) } \\
\text { Ethnicity: } 78 \% \\
\text { non-hispanic } \\
\text { white, } 13 \% \text { his- } \\
\text { panic, } 9 \% \\
\text { black } \\
\text { Diabetes } \\
\text { duration: } m= \\
2.0 \pm 1.5 \text { years } \\
\text { CSIl: } 87 \%\end{array}$ & $\begin{array}{l}\text { Semi-structured, face-to-face } \\
\text { interviews }\end{array}$ & $\begin{array}{l}\text { Guided by a grounded } \\
\text { theory approach }\end{array}$ \\
\hline $\begin{array}{l}\text { Perez } \\
\text { et al., } 2018 \\
{[27]}\end{array}$ & US & $\begin{array}{l}\text { To explore how parents } \\
\text { negotiate the uncertainty } \\
\text { surrounding T1D }\end{array}$ & $\begin{array}{l}n=29 \\
\text { (mother/father } \\
\text { not specified) } \\
\text { Age all parents: } \\
33-50 \text { ( } m=44 \text { ) } \\
\text { Ethnicity: all } \\
\text { Caucasian/ } \\
\text { white } \\
\text { Married: } n=28 \\
\text { (97\%) } \\
\text { In full-time em- } \\
\text { ployment: } n= \\
18 \text { (stay-at- } \\
\text { home: } n=11 \text { ) } \\
\text { Most identified } \\
\text { household } \\
\text { income as } \\
\text { middle to } \\
\text { upper-middle } \\
\text { class }\end{array}$ & $\begin{array}{l}n=30 \\
\text { Age: } 2-17 \\
\text { years }(m= \\
10.9) \\
\text { Age at } \\
\text { diagnosis: } 13 \\
\text { months - } 13 \\
\text { years ( } m=6.5 \\
\text { years) } \\
\text { Diabetes } \\
\text { duration: } 4 \\
\text { months - } 10 \\
\text { years ( } m= \\
\text { 4.39) }\end{array}$ & Interviews (by phone $n=26$ ) & $\begin{array}{l}\text { Thematic analysis as per } \\
\text { Braun \& Clarke (2006) }\end{array}$ \\
\hline $\begin{array}{l}\text { Rankin } \\
\text { et al., } 2015 \\
\text { [29] }\end{array}$ & UK & $\begin{array}{l}\text { To explore parents' experiences } \\
\text { of using an insulin pump to } \\
\text { manage their child's diabetes, } \\
\text { including their views about the } \\
\text { benefits and challenges for } \\
\text { themselves and their child. }\end{array}$ & $\begin{array}{l}n=19(13 \\
\text { mothers) } \\
\text { Age all parents: } \\
34-44 \text { years } \\
\text { ( } m=40.1 \pm 3.7) \\
\text { Ethnicity: all } \\
\text { white British } \\
\text { Married or } \\
\text { cohabiting: } \\
n=18 \\
\text { Higher } \\
\text { education: } n=\end{array}$ & $\begin{array}{l}n=14 \\
\text { Age: } 3-12 \\
\text { years }(m= \\
8.4 \pm 2.8) \\
\text { Age at } \\
\text { diagnosis: } 1-6 \\
\text { years }(m= \\
3.8 \pm 2.1) \\
\text { Length of time } \\
\text { on pump: } 1-4 \\
\text { years }(m= \\
2.2 \pm 1.2)\end{array}$ & Face-to-face interviews & $\begin{array}{l}\text { Thematic analysis using } \\
\text { the method of constant } \\
\text { comparison }\end{array}$ \\
\hline
\end{tabular}


Table 1 Characteristics of studies included in the qualitative synthesis (Continued)

\begin{tabular}{|c|c|c|c|c|c|c|}
\hline Reference & Country & Study aim & $\begin{array}{l}\text { Parent } \\
\text { characteristics }\end{array}$ & $\begin{array}{l}\text { Child } \\
\text { characteristics }\end{array}$ & Method & Data analysis \\
\hline & & & $\begin{array}{l}9 \\
\text { In } \\
\text { employment: } \\
n=12\end{array}$ & & & \\
\hline $\begin{array}{l}\text { Sullivan- } \\
\text { Bolyai } \\
\text { et al., } 2003 \\
{[23]}\end{array}$ & US & $\begin{array}{l}\text { To provide a detailed } \\
\text { description of day-to-day man- } \\
\text { agement experiences of } \\
\text { mothers raising young children } \\
\text { under } 4 \text { years with T1D. }\end{array}$ & $\begin{array}{l}n=28 \text { (all } \\
\text { mothers) } \\
\text { Age: } m=33 \pm \\
5.24 \text { years } \\
\text { Ethnicity: } 89 \% \\
\text { white } \\
\text { Married: } 86 \% \\
\text { Education: } m= \\
15 \pm 2.5 \text { years } \\
\text { Not working } \\
\text { outside of } \\
\text { home: } n=15\end{array}$ & $\begin{array}{l}n=28 \\
\text { Age: } m=2.9 \pm \\
\text { 0.6 years } \\
\text { Diabetes } \\
\text { duration: } m= \\
1.25 \pm 0.7 \text { years }\end{array}$ & Face-to-face interviews & Naturalistic inquiry \\
\hline $\begin{array}{l}\text { Sullivan- } \\
\text { Bolyai } \\
\text { et al., } 2004 \\
{[24]}\end{array}$ & US & $\begin{array}{l}\text { To describe the experiences of } \\
\text { parents managing the T1D of } \\
\text { their young children using an } \\
\text { insulin pump. }\end{array}$ & $\begin{array}{l}n=21(14 \\
\text { mothers) } \\
\text { Age all parents: } \\
\mathrm{m}=38 \pm 3 \\
\text { years } \\
\text { Ethnicity: all } \\
\text { Caucasian } \\
\text { Married: } n=20 \\
\text { Education: } \mathrm{m}= \\
16 \pm 2 \text { years }\end{array}$ & $\begin{array}{l}n=16 \\
\text { Age: } 2-11 \\
\text { years }(m=7 \pm \\
2 \text { years } \\
\text { Length of time } \\
\text { on pump: } 3- \\
36 \text { months } \\
(m=16 \pm 11)\end{array}$ & $\begin{array}{l}\text { In-depth, face-to-face } \\
\text { interviews }\end{array}$ & $\begin{array}{l}\text { Qualitative content } \\
\text { analysis as described by } \\
\text { Sandelowski }\end{array}$ \\
\hline $\begin{array}{l}\text { Sullivan- } \\
\text { Bolyai } \\
\text { et al., } 2006 \\
{[25]}\end{array}$ & US & $\begin{array}{l}\text { To describe fathers' experiences } \\
\text { in parenting and managing the } \\
\text { care of their young children's } \\
\text { day-to-day diabetes regimen. }\end{array}$ & $\begin{array}{l}n=14 \text { (all } \\
\text { fathers) } \\
\text { Age: } m=36 \pm \\
2 \text { years } \\
\text { Ethnicity: all } \\
\text { white } \\
\text { Married: all } \\
\text { Education: } m= \\
16 \pm 2 \text { years } \\
\text { In } \\
\text { employment: } \\
\text { all }\end{array}$ & $\begin{array}{l}n=15 \\
\text { Age: } 2-8 \text { years } \\
(m=5 \pm 2) \\
\text { Diabetes } \\
\text { duration: } 2 \\
\text { weeks }-3 \\
\text { years }(m= \\
1.4 \pm 0.8 \\
\text { months) }\end{array}$ & Face-to-face interviews & $\begin{array}{l}\text { Qualitative content } \\
\text { analysis }\end{array}$ \\
\hline $\begin{array}{l}\text { Watt, } 2017 \\
{[22]}\end{array}$ & Canada & $\begin{array}{l}\text { To explore the emotion work of } \\
\text { doing worry that parents } \\
\text { engage in when caring for their } \\
\text { children with diabetes. }\end{array}$ & $\begin{array}{l}n=7(5 \\
\text { mothers) } \\
\text { Age all parents: } \\
34-53 \text { years } \\
\text { (m=44) } \\
\text { All 2-parent, } \\
\text { middle class } \\
\text { families } \\
\text { Education: all } \\
\text { higher } \\
\text { education }\end{array}$ & $\begin{array}{l}n=\text { not } \\
\text { specified } \\
\text { Age: } 18 \text { years } \\
\text { or younger } \\
\text { Age at } \\
\text { diagnosis: } 9 \\
\text { months - } 14 \\
\text { years }\end{array}$ & $\begin{array}{l}\text { In-depth interviews in the } \\
\text { context of institutional } \\
\text { ethnography (not clear if } \\
\text { face-to-face or phone) }\end{array}$ & $\begin{array}{l}\text { Analysis guided by } \\
\text { Smith's (2005) } \\
\text { conception of work and } \\
\text { analytic questions } \\
\text { suggested by IE scholars } \\
\text { (McCoy, 2006) }\end{array}$ \\
\hline
\end{tabular}

BK and DR evaluated each study using the CASP (Critical Appraisal Skills Programme) quality appraisal tool for qualitative studies [21]. This tool consists of 10 questions considering different aspects of study validity and the perceived value of each study's contribution. The purpose of this systematic appraisal process was not to exclude studies, but to consider strengths and limitations of the included studies.

\section{Data analysis and synthesis}

We conducted a 3-stage thematic synthesis informed by Thomas and Harden's thematic synthesis approach [15]. First, findings from included articles relevant to the aims of the review were coded using free codes that remained close to the original meaning in the primary studies. Second, we compared similarities and differences between the free codes before grouping related data segments into descriptive themes. Finally, we considered the 
Table 2 Primary authors' recommendations to improve parent/ caregiver support in relation to each analytical theme

\section{Monopolisation of life}

To help reduce the detrimental impact on parents' psychological and emotional wellbeing, the primary authors recommended that healthcare professionals could: ascertain and address issues related to hypoglycaemia concerns, lapses in confidence and sleep [23]; and, provide encouragement and support by acknowledging the unpredictability of diabetes and treatment outcomes [22]. More general recommendations included professionals needing to familiarise themselves with the symptoms of burnout [32], and helping parents address any harmful emotions related to their caregiving situation [33]. This could involve: teaching parents strategies to manage negative feelings about the child being 'different' because of diabetes [26]; and, assessing and encouraging parental self-care, including helping to identify sources of respite [23]. Finally, to help reduce anxieties related to social stigma and gendered impacts, primary authors recommended that healthcare professionals seek to improve public awareness and understanding of type 1 diabetes $[27,34,35]$.

To help relieve the care burden on mothers and encourage fathers' involvement, primary authors recommended that professionals should, from the outset, set the expectation that (where possible) both parents attend clinic consultations [28] and that, for respite and emergency purposes, both should be involved in their child's diabetes management [25]. This recommendation could be supported by working with parents to develop a 'division of labour' plan [23].

To alleviate parents' concerns regarding potentially inappropriate diabetes management in daycare settings (e.g. nurseries, schools, playgroups), primary authors recommended that healthcare professionals should help educate staff on safe management practices [23] and, where possible, broaden their outreach work in these settings to increase the number of people available to support the child's diabetes management [28].

To address potential financial pressures related to the child's diabetes treatment, primary authors recommended that healthcare professionals should provide parents with financial guidance about all aspects of diabetes management [27] and offer referral to charitable organisations where appropriate [34].

\section{Parents' experiences of professional and informal support}

To address parents' concerns regarding their diabetes management education and avoid mixed messages, primary authors recommended that healthcare professionals should develop and follow an agreedupon teaching plan; this should include the option of booster sessions, which revisit information and techniques taught at the time of diagnosis [25] and take into consideration individuals' differing speeds of learning and developing confidence [24].

To alleviate potential tensions between parents' and professionals' views regarding diabetes management, primary authors recommended that healthcare professionals should educate parents on their specific clinical perspective [28], while also using parents' knowledge regarding their unique family situation and the child's individual needs to inform treatment decisions [28, 31].

patterns and relationships between these themes to develop interpretations beyond the primary data and generate overarching analytical themes. We then used the same process to compare recommendations made in the Discussion sections of selected articles, by comparing similarities and differences to develop descriptive themes, followed by the generation of analytical themes. We ensured that data pertaining to findings and recommendations were kept separate. This was done to distinguish between themes arising directly from participants' data (findings) and the thematic synthesis of recommendations developed by authors in response to their findings. BK independently coded the extracted data and undertook the synthesis. To reduce bias and enhance rigour, the resultant outputs were discussed with two other review authors (DR and JL) to consider any additions or changes and agree on the final analytic themes.

\section{Results}

The search identified 2622 unique records (see Fig. 1). Of these, 2466 papers were excluded after titles and abstracts were screened for relevance. Full-text review of the remaining 156 studies led to the exclusion of 142 papers that did not meet eligibility criteria. Screening of reference lists of included studies and relevant reviews identified by the search did not identify further papers for inclusion. This resulted in 14 studies being included in the synthesis.

\section{Study characteristics}

The 14 included papers reported the views and experiences of 274 parents in seven countries: Canada [22], United States [23-27], United Kingdom [28-30], Sweden [31, 32], Norway [33], Iran [34] and Palestine [35]. Four papers reported exclusively on the experiences of parents of children aged $\leq 8$ years $(n=80)[23,25,26$, 33]. The remaining 10 also included parents of older children and provided insufficient detail to determine the number of parents with children in our target age group. The provision of information about study participants' sociodemographic characteristics varied greatly. Across all studies, the majority of parents were reported as being: married or co-habiting, qualified to higher education level and in employment. Approximately half of papers specified participants' ethnicity and reported this as mostly, or exclusively, white/Caucasian [23-27, 29]. All studies employed interviews; one additionally used online focus group discussions. Most studies considered parents' holistic experiences of caring for a young child with type 1 diabetes, with some focusing specifically on the experiences of mothers [23, 32, 34] and fathers [25, 31 ], respectively. Two papers described parents' everyday experiences of managing their child's condition using insulin pumps [24, 29]. Table 1 outlines the key characteristics of the included studies.

\section{Quality assessment}

Using the CASP quality appraisal checklist [21], we concluded that all 14 studies had clearly justified and stated research aims, appropriately employed qualitative methodology and provided sufficient information about their data collection processes. However, in some cases it was difficult to determine the rigour of data analysis from the limited information provided. Furthermore, several papers lacked detail regarding their consideration and mitigation of potential researcher influence and ethical 
issues. In respect of their wider contribution, we rated 10 of the 14 studies as being of good value, three of medium and one of low value. The study rated low value used mixed methods to report on a narrow topic area (parents' perceptions of healthy eating for children with type 1 diabetes) [26]. See supplementary Table S1 for the completed CASP scoresheet.

\section{Synthesis findings}

Below, we present two overarching analytical themes resulting from our synthesis, Monopolisation of life and Experiences of professional and informal support, with each theme comprising several subthemes. Primary authors' recommendations for how parent/caregiver support could be improved in respect of the issues identified are summarised in Table 2 .

\section{Monopolisation of life}

\section{Impact on physical, psychological and emotional wellbeing} Across the studies, parents noted how the complexities and unpredictability of type 1 diabetes made it a 'very tiring disease' to manage [25]. They described living in a perpetual state of watchfulness [22, 23, 33 and physical and mental readiness to take action, because '[T] hings may change in minutes' [33]. Consequently, their child's diabetes was permanently present in their minds. As one father explained, 'even if you are not thinking about it [the illness], you are' [25].

Hypoglycaemia, in particular, was an all-pervasive concern [22, 23, 28] borne from several considerations: the child being too young to recognise and report low blood glucose ('he doesn't have a clue, because he's just learning to talk' [28]), some children's poor hypoglycaemia awareness [28, 29]; and, parents' awareness of the potential deadly consequences of hypoglycaemic events [22, 28, 32]. Parents' concerns were greatest during the night, when they worried that severe hypoglycaemia might go undetected and threaten their child's safety. To alleviate their fears, they described testing blood glucose regularly throughout the night, leading to exhaustion and chronic sleep deprivation [22, 23, 33]. Some parents recognised that their actions could be borne from irrational fears, but preferred being hyper-vigilant to having potential future regrets [22, 29]. Some, like this mother, also acknowledged that their efforts came at a cost to their own health and wellbeing:

'I am satisfied in one sense since NN is feeling fine. At the same time, I feel unhappy when I think about not sleeping, feeling anxious and feeling tired and moody all the time.' [32]
Furthermore, despite their child's young age, many parents already worried about how diabetes would affect his/her life in the future [27, 30, 34, 35]:

'I am always thinking about his future. I wonder what will happen to his body. Can he be successful in his life? I do not know; the future is unclear.' [34]

These concerns could be influenced by sociocultural norms and expectations. Parents of young girls in the studies conducted in Iran [34] and Palestine [35] described worrying about their daughter's diabetes harming her chances in marriage, lest she be viewed as less desirable and at risk of passing the condition on to her own children.

In light of parents' varied and constant concerns, many worried about how their emotions might be perceived by, and affect, the child, because, as this mother explained, 'it's hard not to transfer that worry onto him all the time. I know I don't want him to feel worry not going to places or doing things or that sort of thing' [22]. Consequently, they described deliberate efforts to hide their fears, worries and exhaustion by adopting an 'outward façade' [22, 32]. Additionally, some mothers reported depression, weight problems, migraines and episodes of hospitalisation, which they linked to the burden of their caring responsibilities [23].

\section{Impact on relationships}

Several studies highlighted how caregiving responsibilities not only monopolised parents' own lives, but also affected their relationship with the child [23, 30, 32, 33]. Some parents observed how diabetes had 'come between me and my child, and to me that was kind of a feeling of loss' [33]. Managing their child's condition was described as requiring an atypical level of caregiving input [32], with some mothers likening their experience to caring for a newborn [23].

Mothers and fathers also described how their relationships with one another had changed as a result of having to "live with constant attention directed at the diabetes condition' [33]. Mothers typically shouldered the main caring responsibilities [23, 25, 32], with fathers being more willing to be involved in diabetes care when it involved technology [24]. However, fathers still played an important role, especially by providing emotional support and respite to mothers [23, 25, 32, 34]. Some studies indicated potential gender differences in parents' attitudes and approaches to their child's diabetes management, with fathers being more relaxed than mothers in this regard [24, 25, 32]. This could sometimes lead to conflict between parents, but also encouraged more indepth communication about how best to manage their child's diabetes [24]. 


\section{Impact on personal choices and activities}

Parents described caring for a child with type 1 diabetes as a full-time job [32, 33]. They noted that the unpredictability of the condition required them to constantly plan ahead [33]. Accommodating regular clinic appointments required time and flexible employment [25]. Having their child looked after in a daycare facility, including nursery or school, did not necessarily provide respite. Indeed, it could create additional work, as parents needed to ensure that staff were educated about their child's specific care needs and make themselves available throughout the day to answer questions or attend the facility as required [33]. Moreover, the unpredictability of their child's eating and physical activity while at school/nursery could add to parents' anxieties about their child's safety [28]. Mothers also reported feeling concerned about staff's (in) ability to provide appropriate diabetes care and some chose not to place their child in daycare for that reason [23]. Similarly, many parents felt unable to entrust the care of their child to relatives and others in the community, as they perceived them as largely ignorant about diabetes and/or insufficiently vigilant about its management [22, 24, 28, $32]$. Consequently, many mothers curbed personal activities to be available to care for their child [23, 28, 35]. As one mother explained:

'I didn't go to many places, because she couldn't be with me and no one else can take care of her but me.' [35]

These concerns could also affect mothers' employment decisions, with some quitting work or reducing their working hours to allow them to care for their child at home [28]. However, others described how, despite wanting to be stay-at-home caregivers, they needed paid employment to afford their child's diabetes treatment costs [34]. Importantly, this financial strain related to their child's diabetes care was also reported by parents who self-identified as middle- to upper-middle class [27] and were in possession of medical insurance, as this did not always cover all necessary expenses [34, 35].

Finally, several studies described how parents were determined not to let diabetes dominate their child's life $[22,25,26,28,30,32,33]$, so that the child could 'have her innocence, to go out and play and feel like a normal child without feeling there is something different with her' [28]. To facilitate this 'normality', parents adopted strategies that required even more of their time and effort, such as becoming actively involved in school and social activities (e.g. their child's sports team) to allow the child to participate while ensuring a watchful eye on their glucose needs [25] and temporarily relaxing the child's food regimen and later correcting high blood glucose if necessary [26, 28]. Caring for a young child with diabetes also had an all-encompassing impact on wider family life. Some parents reported modifying their own and/or their family's eating practices to make managing mealtimes easier [26]. Bedtimes, leisure activities and holidays were also often adapted to accommodate the child's needs and limited opportunities for spontaneity [32].

\section{Diabetes technologies: lessening the impact}

While most studies illustrated the pervasive impact of the child's diabetes on parents' lives, two studies highlighted how using an insulin pump could alleviate some of the stresses and constraints they experienced [24, 29]. Although parents reported needing to undertake some additional tasks, such as dealing with occasional mechanical problems [24] or more frequent blood glucose checking [29], they also described how pump use had helped reduce the 'slavery of diabetes management' [24] because they no longer needed to administer basal insulin at specific times of day [29], could approach eating and snacking more flexibly due to the ease with which bolus doses could be administered via the pump [24, 29], felt less fearful about their child being cared for by others [24, 29] and found others more willing to babysit [24]. Parents also reported finding it easier to achieve good blood glucose control using a pump due to the ability to administer smaller (more precise) insulin doses, having fewer variables (e.g. only one type of insulin) to manipulate to manage glucose excursions and the pump's data log and bolus advisor helping to reduce management errors [24, 29]. Finally, parents in another study described how using a continuous glucose monitor had helped make treatment decisions easier as it gave them convenient access (via a smart phone app or digital platform such as Nightscout) to realtime blood glucose information and allowed them to review how their child's body responded to different insulin doses throughout the day [27].

\section{Parents' experiences of professional and informal support}

\section{Experiences of professional support}

Parents received their initial education about diabetes management from hospital paediatric diabetes teams. However, they described how sometimes 'one nurse would come in and say do it this way, another would come in and show us a different way' [25], resulting in inconsistencies in the information received. Moreover, parents across several studies considered their initial training inadequate preparation for the daily challenges of caring for a young child with type 1 diabetes [23, 2527, 34]. As this father noted: 
'It is like being handed a big city phone book and you have to learn all the names before you go home.' [25]

While diabetes teams were generally considered a helpful resource, some parents felt that professionals did not always appreciate the complex and dynamic nature of managing diabetes at home [31] and the considerable effort this required [23]. Furthermore, staff not making time to answer questions or calls, avoiding discussion of more holistic issues and offering inaccurate or inconsistent advice could undermine parents' trust in their diabetes team [31]. Some parents described how they felt stressed and anxious in the run-up to clinic appointments for fear of being reprimanded for a (perceived) lack of effort and not meeting blood glucose targets [23, $28,32]$. This fear also led to some actively withholding information from the diabetes team [23] and was felt even in the absence of any critical comments from staff [32].

Several studies also highlighted potential conflict between parents' and professionals' diabetes expertise. The fathers in Boman's study described a mismatch between their own personal experiences of caring for a child with diabetes and the general recommendations and goals put forward by the diabetes team [31]. Parents in another study felt that healthcare professionals had unrealistic expectations of what was achievable in terms of their young child's blood glucose control [28]. Indeed, many emphasised how their unique personal understanding of their child's individual needs and their impact on everyday life provided them with insights that extended beyond professionals' focus on glycaemic control [22, 28, 31]. As this father of a 4-year-old reported:

'I have a larger backpack than the professionals' knowledge of HbA1c. Yes, it's an individual who is affected, but in everyday life it [the diabetes] controls the whole family's life, and then you have to have more in your backpack than just HbA1c.' [31]

Relatedly, some parents described how professionals tended to focus exclusively on the needs of the child and failed to acknowledge how some parents may be struggling to cope with the strains of diabetes management in the context of wider family life [32].

\section{Experiences of informal support}

Parents described drawing on informal sources to support the management of their child's diabetes. Most often, this involved their spouses/partners [23, 25, 33] or other family members [23], although their support could be limited due to relatives' poor diabetes knowledge and understanding [32]. While parents craved social contact with other families, their caring responsibilities made them feel different to others and they reported struggling to feel fully present in social situations [33]. Some parents, like this mother, credited support groups with making them feel less isolated and able to vent their frustrations about the challenges of providing diabetes care:

'I am in a diabetes support group with moms and I find I've learned a lot from what other moms do ... I can say, oh my goodness, today is making me crazy and I can't figure it out and diabetes is not fun right now.' [22]

Moreover, parents considered their peers a vital source of information when professional advice was deemed insufficient [34] or, as this mother explained, difficult to access [27]:

'Facebook groups were also super helpful, because it was really nice to be able to post a question like, "How do you guys do this, or what should I do about this?" ... because we did have the number to call, but getting hold of the doctor or educator was just a huge pain, and sometimes you don't know if your question is big enough to call the doctor about.' [27]

\section{Discussion}

This review is the first to synthesise and describe the findings from qualitative studies, which report parents' everyday experiences of caring for a child aged $\leq 8$ years with type 1 diabetes. It highlights the all-encompassing, relentless and enduring nature of parents' care experiences and how their lives are dominated by constant worry, the need to be vigilant and a desire to enable their child to have a 'normal' childhood. Moreover, the synthesis illustrates how caregiving responsibilities could be detrimental to parents' own physical, psychological and emotional well-being, relationships, personal choices and everyday activities. Parents' encounters with healthcare professionals, while generally perceived as helpful, could add to their anxieties and frustrations, as could lack of access to trusted sources of childcare and informal support. Conversely, connecting with other parents who had a child with type 1 diabetes constituted an important source of emotional and practical support. The synthesised recommendations by primary authors presented in Table 2 highlight ways in which clinical practice might be adapted to help alleviate parents' care burden, improve their emotional and educational support, and foster more collaborative working between parents and professionals. 
Some parents, particularly mothers, described how they were forced to make decisions about employment based on their child's diabetes care needs and associated expenses. Furthermore, even parents who self-identified as middle-class and were in possession of medical insurance reported experiencing diabetes-related financial strains due to at least some treatment supplies needing to be paid for through personal means. Resonating with these findings, a survey conducted with parents of young children with type 1 diabetes found that having a child with diabetes influenced the employment decisions of $60 \%$ of parents $(89.5 \%$ of them mothers), with nearly one quarter reducing or quitting work and others maintaining employment for financial reasons [36]. Research has also shown that caring for a child with type 1 diabetes was significantly more detrimental to their work and finances compared with parents of children with other or no special healthcare needs [37]. The study samples in our synthesis were skewed towards co-habiting and working parents; hence, our findings raise important questions and concerns about how parents living in lowincome countries or on low incomes (including single parents, who are more likely to report lower incomes and benefit dependency [38]) manage the practical and financial demands of their child's diabetes care.

Some parents described how using insulin pumps and glucose sensors helped reduce the stresses and constraints diabetes management placed on everyday life. The use of insulin pumps in paediatric populations has risen considerably in recent years [39] and insulin pump therapy is now the recommended method of insulin administration in young children [40]. These developments suggest that greater numbers of parents are now using insulin pumps than when some of the included studies were conducted. Research suggests that newer technologies, such as continuous glucose monitors and closedloop systems, are likely to help further ease the burden of diabetes management. For example, use of continuous glucose monitors may lessen parental anxiety due to the device alerting them to hypo- and hyperglycaemia [41], while those able to monitor their child's glucose data remotely may experience improved sleep and greater lifestyle freedoms [42, 43]. Similarly, while user evaluations of closed-loop systems have mainly involved older participant groups with type 1 diabetes and/or their parents [44-48], preliminary trials involving very young children suggest that this technology can help parents feel less burdened by diabetes management tasks and facilitate better sleep [49].

Several parents reported benefitting from the emotional and practical support provided by other parents of children with type 1 diabetes via support groups and online fora. Conversely, while parents were generally appreciative of the support provided by healthcare professionals, some described how this contact could make them feel frustrated and anxious. They also described receiving inadequate diabetes education following their child's diagnosis and conflicting messages from different healthcare professionals. These issues are noteworthy as, arguably, they could be adding to the psychological and emotional burden parents experience. Other studies have described how parents wish for a tailored, collaborative approach to their education and clearer, more sensitive communication from diabetes professionals [50]. Moreover, it has been noted that parents feeling anxious during diabetes consultations can affect their ability to concentrate, and thus assimilate, the information provided [51]. As appropriate patient education and communication is critical to achieving positive behaviour change in diabetes management [52], diabetes teams should urgently consider the quality of their communication and parents' emotional needs during clinical encounters. Primary authors' recommendations, such as adopting a collaborative approach to engaging with parents (Table 2), provide a useful starting point for diabetes teams to consider and build upon.

This review and synthesis was conducted in accordance with established methods for the systematic reviewing, appraising and synthesising of qualitative studies $[15,21]$ and reported according to published guidelines $[16,17]$. Nevertheless, we acknowledge that syntheses, by their nature, cannot convey the contextual richness of the individual studies upon which they draw. We also recognise that our decision to exclude papers not published in English may have resulted in the final sample containing fewer studies from lower-income countries. However, our reporting is strengthened by the consistency of findings observed across the primary studies, despite these having been conducted in a diversity of countries with different cultures and healthcare systems. We also recognise the potential influence of our unique perspectives as UK-based, non-clinical researchers throughout the analytic process and in the presentation of results.

The limitations inherent in the primary studies included in this synthesis highlight important considerations for future research. The study samples were biased towards parents who were married or cohabiting, qualified to higher education level, in employment and white/Caucasian. Consequently, the experiences and views presented in this synthesis may not reflect those of other parents caring for a young child with type 1 diabetes. Indeed, while we found good consistency of findings across the studies, they did indicate potentially divergent challenges related to income and cultural norms. Other studies suggest that education, financial status, family make-up and ethnicity may differentially affect parents' ability to manage and cope 
with diabetes [53, 54] and, importantly, influence children's diabetes outcomes [55]. Consequently, it is vital that future research considers the experiences and views of parents of different demographic and socioeconomic backgrounds and those living in low-income countries and settings. Moreover, as parents' experiences, and thus support needs, may be more diverse than the current literature shows, providing more detailed participant data will help practitioners draw more nuanced conclusions from study findings. Finally, given the potential positive impact of newer diabetes technologies, such as closedloop systems, qualitative studies could explore the experiences of parents caring for very young children with type 1 diabetes using these newer technologies and assess whether, and how, they help address some of the challenges highlighted in this review.

\section{Conclusions}

The current literature consistently describes caring for a young child with type 1 diabetes as an all-encompassing and relentless undertaking, which can have a detrimental impact on parents' own well-being, relationships, personal choices and everyday activities. However, significant limitations and gaps in this literature mean that parents' experiences may in fact be more diverse than is currently recognised, which could have implications for the support they require from healthcare professionals. In particular, we recommend that future research should explore how sociodemographic factors and use of newer diabetes technologies influence parents' diabetes management practices and experiences of caring for a young child with type 1 diabetes.

\section{Abbreviations \\ ENTREQ: Enhancing Transparency of Reporting the Synthesis of Qualitative Research; PRISMA: Preferred Reporting Items for Systematic Reviews and Meta-Analyses; MeSH: Medical Subject Heading; SPIDER: Sample, \\ Phenomenon of Interest, Design, Evaluation, Research type; CASP: Critical Appraisal Skills Programme}

\section{Supplementary Information}

The online version contains supplementary material available at https://doi. org/10.1186/s12887-021-02569-4.

Additional file 1: Table S1. CASP quality appraisal scoresheet

Additional file 2: Fig. S1. Exemplar search strategy from Medline database

\section{Acknowledgements}

The authors would like to thank Cameron Werner and Marshall Dozier, Medical Librarian at the University of Edinburgh, for their help developing the search strategy.

\section{Authors' contributions}

All authors (BK, JL, CB, RH and DR) contributed to the design of this review. $B K$ and DR conducted the literature search, screening and quality assessment. BK extracted and coded the data, analysed the data with input from $D R$ and $J L$, and drafted the initial manuscript. All authors (BK, $J, C B, R H$ and DR) critically reviewed and approved the final manuscript.

\section{Funding}

This review was undertaken as part of a research project funded by the European Union's Horizon 2020 research and innovation programme under the grant agreement No 731560. This material reflects only the authors' views and the Commission is not liable for any use that may be made of the information contained therein. $\mathrm{RH}$ is supported by the National Institute of Health Research Cambridge Biomedical Research Centre.

Availability of data and materials

Not applicable.

Ethics approval and consent to participate

Not applicable.

\section{Consent for publication}

Not applicable.

\section{Competing interests}

$\mathrm{RH}$ reports having received speaker honoraria from Eli Lilly and Novo Nordisk, serving on advisory panels for Eli Lilly and Novo Nordisk; receiving license fees from BBraun and Medtronic; having served as a consultant to BBraun, patents and patent applications related to closed-loop insulin delivery, and director at CamDiab. BK, JL, CB and DR have no competing interests to report.

\section{Author details}

${ }^{1}$ Centre for Population Health Sciences, Usher Institute, University of Edinburgh, Edinburgh, UK. ${ }^{2}$ Wellcome Trust - MRC Medical Research Institute of Metabolic Science, University of Cambridge, Cambridge, UK. ${ }^{3}$ Department of Paediatrics, University of Cambridge, Cambridge, UK.

Received: 15 October 2020 Accepted: 24 February 2021

Published online: 04 April 2021

\section{References}

1. Craig M, Hattersley A, Donaghue KC. Definition, epidemiology and classification of diabetes in children and adolescents. Pediatr Diabetes. 2009; 10:3-12.

2. Patterson CC, Harjutsalo V, Rosenbauer J, Neu A, Cinek O, Skrivarhaug T, et al. Trends and cyclical variation in the incidence of childhood type 1 diabetes in 26 European centres in the 25 year period 1989-2013: a multicentre prospective registration study. Diabetologia. 2019;62:408-17.

3. Silverstein J, Klingensmith G, Copeland K, Plotnick L, Kaufman F, Laffel L, et al. Care of children and adolescents with type 1 diabetes. Astatement Am Diabetes Assoc. 2005;28:186-212.

4. Streisand R, Monaghan M. Young children with type 1 diabetes: challenges, research, and future directions. Curr Diabetes Rep. 2014:14:520.

5. Wood JR, Miller KM, Maahs DM, Beck RW, DiMeglio LA, Libman IM, et al. Most youth with type 1 diabetes in the T1D exchange clinic registry do not meet American Diabetes Association or International Society for Pediatric and Adolescent Diabetes clinical guidelines. Diabetes Care. 2013;36:2035-7.

6. Whittemore R, Jaser S, Chao A, Jang M, Grey M. Psychological experience of parents of children with type 1 diabetes: a systematic mixed-studies review. Diabetes Educ. 2012;38:562-79.

7. Rankin D, Harden J, Waugh N, Noyes K, Barnard KD, Lawton J. Parents' information and support needs when their child is diagnosed with type 1 diabetes: a qualitative study. Health Expect. 2016;19:580-91.

8. Sparud-Lundin C, Hallstrom I, Erlandsson L-K. Challenges, strategies, and gender relations among parents of children recently diagnosed with type 1 diabetes. J Fam Nurs. 2013;19:249-73.

9. Alsaleh FM, Smith FJ, Thompson R, Al-Saleh MA, Taylor KM. Insulin pump therapy: impact on the lives of children/young people with diabetes mellitus and their parents. Int J Clin Pharm. 2014;36:1023-30.

10. Forsner M, Berggren J, Masaba J, Ekbladh A, Olinder AL. Parents' experiences of caring for a child younger than two years of age treated with continuous subcutaneous insulin infusion. Eur Diab Nurs. 2014;11:7-12.

11. Lin H, Mu P, Lee Y. Mothers' experience supporting life adjustment in children with T1DM. West J Nurs Res. 2008;30:96-110.

12. Hannes $\mathrm{K}$, Lockwood C. Synthesizing qualitative research: choosing the right approach. Chichester: Wiley; 2012. 
13. Lowes L, Lyne P. Chronic sorrow in parents of children with newly diagnosed diabetes: a review of the literature and discussion of the implications for nursing practice. J Adv Nurs. 2000;32:41-8.

14. Alsaleh FM, Smith FJ, Taylor KM. Experiences of children/young people and their parents, using insulin pump therapy for the management of type 1 diabetes: qualitative review. J Clin Pharm Ther. 2012;37:140-7.

15. Thomas J, Harden A. Methods for the thematic synthesis of qualitative research in systematic reviews. BMC Med Res Methodol. 2008;8:45.

16. Tong A, Flemming K, Mclnnes E, Oliver S, Craig J. Enhancing transparency in reporting the synthesis of qualitative research: ENTREQ. BMC Med Res Methodol. 2012;12:181

17. Moher D, Liberati A, Tetzlaff J, Altman DG. Preferred reporting items for systematic reviews and meta-analyses: the PRISMA statement. PLoS Med. 2009;6:e1000097.

18. Cooke A, Smith D, Booth A. Beyond PICO: the SPIDER tool for qualitative evidence synthesis. Qual Health Res. 2012;22:1435-43.

19. DAFNE Study Group. Training in flexible, intensive insulin management to enable dietary freedom in people with type 1 diabetes: dose adjustment for normal eating (DAFNE) randomised controlled trial. Brit Med J. 2002;325: 746-9.

20. Fornasini S, Miele F, Piras E. The consequences of type 1 diabetes onset on family life. An integrative review. J Child Fam Stud. 2020;29(5):1467-83.

21. Critical Appraisal Skills Programme. CASP Qualitative Checklist 2018. [online] Available at: https:/casp-uk.net/wp-content/uploads/2018/03/CASP-Qualita tive-Checklist-2018_fillable_form.pdf Last accessed: 10 Dec 2019.

22. Watt L. "Her life rests on your shoulders": doing worry as emotion work in the care of children with diabetes. Glob Qual Nurs Res. 2017;4: 2333393617743638

23. Sullivan-Bolyai S, Deatrick J, Gruppuso P, Tamborlane W, Grey M. Constant vigilance: Mothers' work parenting young children with type 1 diabetes. J Pediatr Nurs. 2003;18:21-9.

24. Sullivan-Bolyai S, Knafl K, Tamborlane W, Grey M. Parents' reflections on managing their children's diabetes with insulin pumps. J Nurs Schol. 2004; 36:316-23.

25. Sullivan-Bolyai S, Rosenberg R, Bayard M. Fathers' reflections on parenting young children with type 1 diabetes. MCN Am J Matern Chil. 2006;31:24-31.

26. Patton SR, Clements MA, George K, Goggin K. "I don't want them to feel different": a mixed methods study of parents' beliefs and dietary management strategies for their young children with type 1 diabetes mellitus. J Acad Nutr Diet. 2016;116:272-82.

27. Perez L, Romo LK, Bell T. Communicatively exploring uncertainty management of parents of children with type 1 diabetes. Health Commun. 2018. https://doi.org/10.1080/10410236.2018.1446249.

28. Lawton J, Waugh N, Barnard KD, Noyes K, Harden J, Stephen J, et al. Challenges of optimizing glycaemic control in children with type 1 diabetes: a qualitative study of parents' experiences and views. Diabet Med. 2015:32:1063-70.

29. Rankin D, Harden J, Noyes K, Waugh N, Barnard K, Lawton J. Parents' experiences of managing their child's diabetes using an insulin pump: a qualitative study. Diabet Med. 2015;32:627-34.

30. Marshall M, Carter B, Rose K, Brotherton A. Living with type 1 diabetes: perceptions of children and their parents. J Clin Nurs. 2009;18:1703-10.

31. Boman $\AA$, Povlsen L, Dahlborg-Lyckhage E, Hanas R, Borup I. Fathers' encounter of support from paediatric diabetes teams; the tension between general recommendations and personal experience. Health Soc Care Commun. 2013;21:263-70.

32. Lindström C, Åman J, Norberg AL, Forssberg M, Anderzén-Carlsson A. "Mission impossible"; the mothering of a child with type 1 diabetes - from the perspective of mothers experiencing burnout. J Pediatr Nurs. 2017;36:149-56.

33. Iversen AS, Graue M, Haugstvedt A, Raheim M. Being mothers and fathers of a child with type 1 diabetes aged 1 to 7 years: a phenomenological study of parents' experiences. Int J Qual Stud Health Well-Being. 2018;13:1487758.

34. Khandan M, Abazari F, Tirgari B, Cheraghi MA. Lived experiences of mothers with diabetic children from the transfer of caring role. Int J Community Nurs Midwifery. 2018;6:76-88.

35. Elissa K, Bratt EL, Axelsson ÅB, Khatib S, Sparud-Lundin C. Societal norms and conditions and their influence on daily life in children with type 1 diabetes in the West Bank in Palestine. J Pediatr Nurs. 2017;33:16-22.

36. Herbert LJ, Wall K, Monaghan M, Streisand R. Parent employment and school/daycare decisions among parents of young children with type 1 diabetes. Child Health Care. 2017;46:170-80.
37. Katz ML, Laffel LM, Perrin JM, Kuhlthau K. Impact of type 1 diabetes mellitus on the family is reduced with the medical home, care coordination, and family-centered care. J Pediatr. 2012;160:861-7.

38. Thompson SJ, Auslander WF, White NH. Comparison of single-mother and two-parent families on metabolic control of children with diabetes. Diabetes Care. 2001;24:234-8.

39. van den Boom L, Karges B, Auzanneau M, Rami-Merhar B, Lilienthal E, von Sengbusch S, et al. Temporal trends and contemporary use of insulin pump therapy and glucose monitoring among children, adolescents, and adults with type 1 diabetes between 1995 and 2017. Diabetes Care. 2019;42:2050.

40. Sundberg F, Barnard K, Cato A, de Beaufort C, DiMeglio LA, Dooley G, et al. ISPAD guidelines. Managing diabetes in preschool children. Pediatr Diabetes. 2017;18:499-517.

41. Haslund-Thomsen $H$, Hasselbalch LA, Laugesen B. Parental experiences of continuous glucose monitoring in Danish children with type 1 diabetes mellitus [published online ahead of print, 2020 Mar 31]. J Pediatr Nurs. 2020 https://doi.org/10.1016/j.pedn.2020.03.010.

42. Burckhardt MA, Fried L, Bebbington K, Hancock M, Nicholas JA, Roberts A, et al. Use of remote monitoring with continuous glucose monitoring in young children with type 1 diabetes: the parents' perspective. Diabet Med. 2019;36:1453-9.

43. Lee JM, Newman MW, Gebremariam A, Choi P, Lewis D, Nordgren W, et al. Real-world use and self-reported health outcomes of a patient-designed do-it-yourself mobile technology system for diabetes: lessons for mobile health. Diabetes Technol Ther. 2017;19:209-19.

44. Hendrieckx C, Poole LA, Sharifi A, Jayawardene D, Loh MM, Horsburgh JC, et al. "It is definitely a game changer": a qualitative study of experiences with in-home overnight closed-loop technology among adults with type 1 diabetes. Diabetes Technol Ther. 2017;19:410-6.

45. Barnard KD, Wysocki T, Allen JM, Elleri D, Thabit H. Leelarathna L et al closing the loop overnight at home setting: psychosocial impact for adolescents with type 1 diabetes and their parents. BMJ Open Diabetes Res Care. 2014:2:e000025.

46. Lawton J, Blackburn M, Rankin D, Allen JM, Campbell FM, Leelarathna L, et al. Participants' experiences of, and views about, daytime use of a dayand-night hybrid closed-loop system in real life settings: longitudinal qualitative study. Diabetes Technol Ther. 2019;21:119-27.

47. Farrington C, Stewart Z, Barnard K, Hovorka R, Murphy H. Experiences of closed-loop insulin delivery among pregnant women with type 1 diabetes. Diabet Med. 2017;34:1461-9.

48. Barnard KD, Wysocki T, Ully V, Mader JK, Pieber TR, Thabit H, et al. Closing the loop in adults, children and adolescents with suboptimally controlled type 1 diabetes under free living conditions: a psychosocial substudy. J Diabetes Sci Technol. 2017:11:1080-8.

49. Musolino G, Dovc K, Boughton CK, Tauschmann M, Allen JM, Nagl K, et al. Reduced burden of diabetes and improved quality of life: experiences from unrestricted day-and-night hybrid closed-loop use in very young children with type 1 diabetes. Pediatr Diabetes. 2019;20:794-9.

50. Buckloh LM, Lochrie AS, Antal H, Milkes A, Canas JA, Hutchinson S, et al. Diabetes complications in youth - qualitative analysis of parents' perspectives of family learning and knowledge. Diabetes Care. 2008;31: 1516-20.

51. Lawton J, Waugh N, Noyes K, Barnard K, Harden J, Bath L, et al. Improving communication and recall of information in paediatric diabetes consultations: a qualitative study of parents' experiences and views. BMC Pediatr. 2015;15:67.

52. Hood KK, Hilliard M, Piatt G, Levers-Landis CE. Effective strategies for encouraging behavior change in people with diabetes. Diabetes Manag (London). 2015;5:499-510.

53. Harrington KR, Boyle CT, Miller KM, Hilliard ME, Anderson BJ, Van Name M, et al. Management and family burdens endorsed by parents of youth $<7$ years old with type 1 diabetes. J Diabetes Sci Technol. 2017;11:980-7.

54. Edmonds-Myles S, Tamborlane W, Grey M. Perception of the impact of type 1 diabetes on low-income families. Diabetes Educ. 2010;36:318-25.

55. Pierce JS, Kozikowski C, Lee JM, Wysocki T. Type 1 diabetes in very young children: a model of parent and child influences on management and outcomes. Pediatr Diabetes. 2017;18:17-25.

\section{Publisher's Note}

Springer Nature remains neutral with regard to jurisdictional claims in published maps and institutional affiliations. 